\title{
Isolation and Molecular Characterization of Local Goat Milk Casein for Nutraceutical Value
}

\author{
Mohd Akmal Azhar ${ }^{1, *}$, and Norshafiqa Salim ${ }^{2}$ \\ ${ }^{1}$ Faculty of Engineering Technology, UMP Gambang, Lebuhraya Tun Razak, 26300, Kuantan, Pahang, \\ Malaysia \\ ${ }^{2}$ Politeknik Nilai, Kompleks Pendidikan Bndr Enstek, 71760 Bandar Enstek, Negeri \\ Sembilan,Malaysia
}

\begin{abstract}
Bioactive peptide from casein play a very important role in biological functionalities such as antioxidant and antimicrobial activities. Casein is the main protein that derived from goat milk which consists of alpha $(\alpha)$, beta $(\beta)$ and kappa $(\kappa)$ casein. Dietary protein such as casein from animal can provide rich source of bioactive peptide. However, the macromolecular protein such as cow milk can cause allergic response to certain individuals. On the other hand, goat milk have been known for its hypoallergenic and therapeutic properties in human nutrition and health. The purpose of this study is to extract casein from local breed goat milk and identify the molecular characterization of casein for nutraceutical value. The casein was successfully extracted using extraction method. Extraction is a common technique used to separate a desired substance when it is mixed with other components. The average percentage of casein obtained was $24.25 \%$. Then, the casein was analysed by running it in the SDS-Page. The major fraction is $\beta$-casein and the minor is $\alpha$-casein that can be seen between $20 \mathrm{kDa}$ and $30 \mathrm{kDa}$ respectively. There is no contaminated protein appear in the purified $\alpha$-amylase. The result obtained in this study indicates that isolated casein from Malaysian goat milk was pure and can be used as bioactive peptide for nutraceutical value.
\end{abstract}

\section{Introduction}

Nutraceutical food may provide numerous benefits to the consumers because of the active components of the food. Nowadays, A lot of scientific research indicate health are mostly related to food consumption resulting to increase a concern regarding functional food [1]. Although several plant and animal can be the source of bioactive peptide, however milk protein have become the main source of bioactive peptide for functional food [2]. Bioactive peptide from casein play a very important role in biological functionalities such as antioxidant, antimicrobial, antihypertensive, oploid and mineral carrying activities. Researcher for the last decade has provided that biologically active peptide release from casein contain 3 to 20 amino acid per molecule [3]. The increasing knowledge of this bioactive compound have lead the demand of obtaining of this component in enriched purified form. Casein fraction have been prove to be biologically active and also good source

*Corresponding author: akmalba@ump.edu.my 
of different bioactive peptide. It is known to have good nutritive value such as amino acids, calcium, phosphate and several trace elements. Dietary protein such as casein from animal can provide rich source of bioactive peptide. However, the macromolecular protein such as cow milk and whey protein can cause allergic response to certain individuals. On the other hand, goat milk have been known for its hypoallergenic and therapeutic properties in human nutrition and health. The demand of goat milk was increase dramatically worldwide when people start to notice that goat milk are better than bovine milk in term of nutrient, flavour and digestion. Goat milk is vary in term of nutritional properties, composition and biological stability depending on the genetic factor and goat farming practices [4]. The interest of goat milk as a functional food has become the current trend to developed country because the advantages of the nutritional properties compared to cow's milk. The lower allergenicity especially toward children increases the popularity of goat milk as the functional food. The aims of this study are to isolate and purified the protein casein from local breed goat milk which is the Boer and Saanen species. This study also aims to identify the molecular characterization of the isolated casein.

\section{Materials and methods}

\subsection{Sample collection}

Goat milk sample was obtained from Tanjung Agrofarm at Nilai, Negeri Sembilan. The milk was brought back to the laboratory of Nilai Polytechnic. The container was placed in a sterile condition and kept in the chiller at $5^{\circ} \mathrm{C}$ for further use.

\subsection{Preparation of whole casein}

The whole casein preparation was done using acid precipitation method [5]. The procedure involves the following steps. The fresh goat milk was centrifuge at 4000rpm for 20 minutes at $20^{\circ} \mathrm{C}$. The upper layer is discarded and supernatant skim milk was collected. The $\mathrm{pH}$ of supernatant was adjusted to 4.6 with $1 \mathrm{M} \mathrm{HCl}$ by slow stirring. The mixture was centrifuge for 15 minutes at $4000 \mathrm{rpm}$. The pellet was washed using ethanol and acetate buffer for three times and analysed by SDS-PAGE electrophoresis.

\subsection{Purification of $\alpha$-casein}

The $\alpha$-casein was purified by urea fractionation method [6]. The procedure involves the following steps. Casein was dissolve in $6.6 \mathrm{M}$ urea. The molarity of the urea was reduced to 4.6 by diluted with water slowly and stirred. The solution was centrifuge for 20 minutes at $4000 \mathrm{rpm}$ at $20^{\circ} \mathrm{C}$. This pellet was dissolved in $6.6 \mathrm{M}$ urea containing $0.15 \mathrm{M} \mathrm{NaCl}$ and diluted to $4.6 \mathrm{M}$ urea. The pellet was separated by centrifugation and analysed by SDS-PAGE electrophoresis.

\subsection{Protein molecular weight determination}

Prepared proteins were separated on polyacrylamide gel electrophoresis as describe by [7]. The purified caseins were dissolved with $1 \mathrm{M} \mathrm{NaOH}$ before mixed with an equal volume of sample buffer. After gel polymerization, $20 \mu \mathrm{g}$ proteins were applied to each lane in the gel. The electrophoresis was performed using mini-protein Tetra system with $10 \%$ acrylamide gel at $150 \mathrm{~V}$ for 40 minutes. The proteins were visualized on the gel coomassie blue staining $(0.1 \%$ coomassie blue brilliant blue in $50 \%$ methanol and $10 \%$ acetic acid). 


\section{Results and discussions}

The average percentage of casein extracted from goat milk was $24.25 \%$. This figure was obtained by calculate the total dry weigh of casein extracted by acid precipitation method. It is agree with the result obtained from [8] where it state that the casein protein extracted from whole milk was around $21-27 \%$. Figure 1 shows the casein extracted from local goat milk which was observed to be white in colour. The casein was in semi-solid form after the drying method was done.

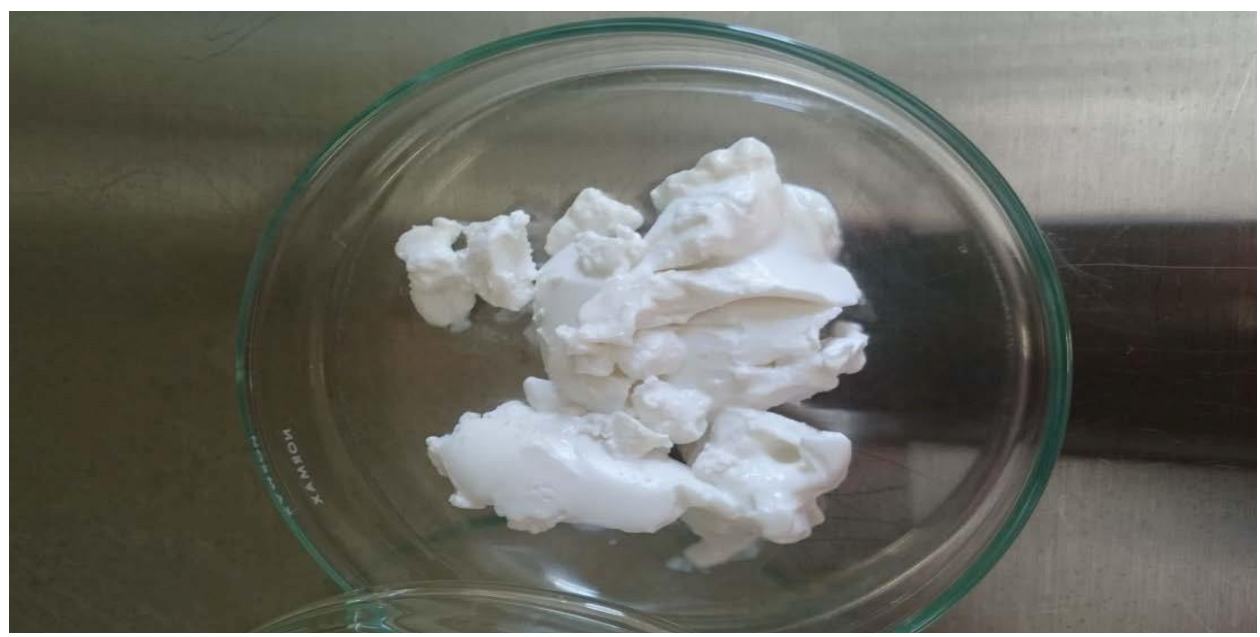

Fig. 1. Isolated casein

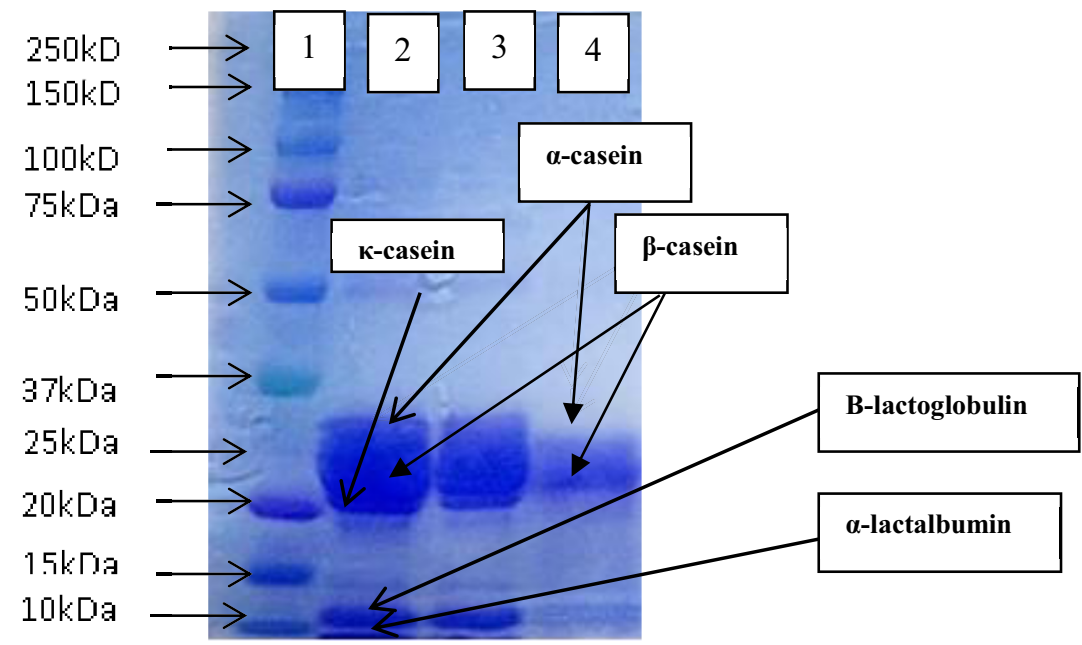

Fig. 2. SDS page of goat milk. Lane 1: Standard protein marker. Lane 2 and 3: Whole goat milk. Lane 4: whole casein protein.

The SDS-PAGE electrophoresis patterns of protein from goat milk are presented in figure 2 . Lane 1 shows the whole goat milk that contain three major band which were $\alpha$-casein, $\beta$-casein and $\kappa$-casein. Another two minor band were identified as $\beta$-lactoglobulin and $\alpha$-lactalbumin. Lane 2 shows the whole casein extraction. The major fraction is $\beta$-casein and the minor is $\alpha$-casein that can be seen between $20 \mathrm{kDa}$ and $30 \mathrm{kDa}$ at lane 4 . No major band of 
contaminating cross proteins were observed in whole goat milk as well as whole casein extraction. Both were reasonably pure because only relevant bands were obtained in the SDS-PAGE. However, it was difficult to differentiate $\beta$-casein and $\kappa$-casein in the whole casein fraction. Although the molecular weight of casein fractions fall in the range 19-25 $\mathrm{kDa}$. This result agrees with other reported data [9], where it state that the dominant fraction of casein is $\beta$-casein which is $70.2 \%$ while $\alpha$-casein is the minor which is $29.8 \%$.

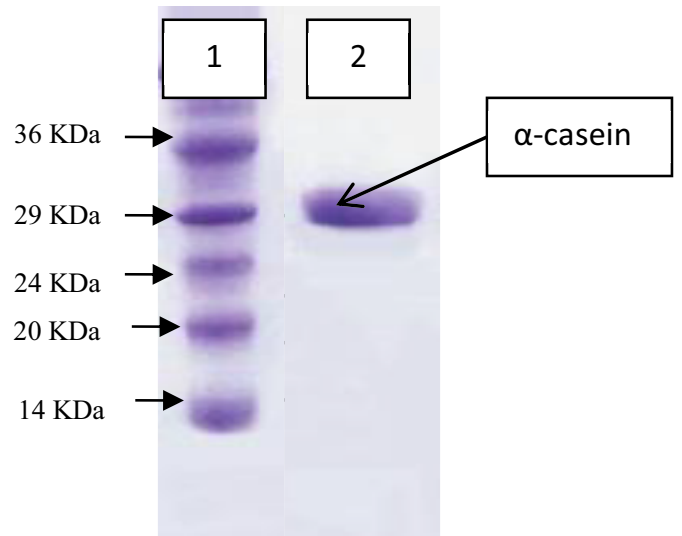

Fig. 3. SDS page of goat milk. Lane 1: Standard protein marker. Lane 2: purified $\alpha$-casein

Figure 3 shows that one single band without any protein contamination for $\alpha$-casein after purified using fractionation method. It was stated by [10] that the molecular of $\alpha$-casein and $\beta$-casein were estimated at $30.2 \mathrm{kDa}$ and $23.9 \mathrm{kDa}$ respectively. This result shown that the isolated casein has the molecular weight at the range of previous study. In general, the protein in milk from different species have different characteristic therefore affected the protein proportion. However, many of them shared approximately the same molecular weight because the similarity amino acid composition.

\section{Conclusion}

Goat milks protein from local breed goat (Malaysia) was extracted by using acid precipitation method and purified using urea fractionation. The source of whole milk was validate as pure goat milk based on the absence of other contaminated protein and the presence of five major types of protein. The whole casein preparation and purified $\alpha$-casein can be validate as pure casein and pure $\alpha$-casein because it was identified to have the dominant proportion which are $\alpha$ - and $\beta$ - casein in the whole casein while only $\alpha$-casein band in purified $\alpha$-casein based on the SDS-Page identification. Hence, the result suggests that isolated casein from Malaysian goat milk was pure and can be used as bioactive peptide for nutraceutical value.

This work was financially supported by grant from UMP (RDU 1403146). The authors are grateful to Tanjung Agrofarm, Nilai for donating the milk samples.

\section{References}

1. A.C. Ribeiro, S.D.A. Ribeiro, Small Rumin. Res., 89, 225 (2010)

2. J. Dziuba, P. Minkiewicz, D. Nalecz, Polish J. Food Nutr. Sci., 849, 3 (1999)

3. Y.W. Park, Bioactive components in milk and dairy products. (Wiley-Blackwell, USA, 2009) 
4. F. Yangilar, J. Food Nutr. Res., 1, 68 (2013)

5. S. Srinivas, V. Prakash, Int. J. Pept. Res. Ther., 16, 7 (2009)

6. R. Aschaffenburg, J. Dairy Res., 30, 259 (1963)

7. U.K. Laemmli, Nature, 227, 680 (1970)

8. N.K. Kamizake, M.M. Goncalves, C.T.B. Zaia, D.A. Zaia, J. Food Compos. Anal., 16, 507 (2003)

9. S.A. Salem, E.I. El Agamy, F.A. Salama, N.H. Abo Soliman, Trop. Subtrop. Agroecosystems, 11, 29 (2009)

10. E.I. El Agamy, Z.I. Abou Shloue, Y.I. Abdel Kader, Third Alexandria Conference on Food Science and Technology, (1997) 